\title{
Türkiye'deki İş Kazalarının Zaman Serisi Analiz Teknikleri ve Yapay Sinir Ağları Tekniği île İncelenmesi
}

\author{
Investigation of Work Accidents in Turkey with Time Series Analysis \\ and Neural Network Technique
}

\section{Barış ERGÜL}

\section{ÖZET}

İş kazaları sonucunda ölüm ve iş göremezlik verileri yıllara göre kaydedilmektedir. Yıllar bazında kaydedilen veriler zaman serisi analizi ile modellenmektedir. Bu çalışmada, Türkiye'deki iş kazaları sonucu ölüm sayıları ve sürekli iş göremezlik sayıları, Box-Jenkins (ARIMA) Tekniği ile modellenmiştir. Ayrıca aynı veriler Yapay Sinir Ağları ile de modellenmiştir. Her iki yöntem sonucunda elde edilen modeller, tahmin bakımından karşılaştırılmıştır. 2016-2020 yılları için yapılan tahminlere göre, Yapay Sinir Ağları ile kurulan model daha doğru tahmin değerleri vermiştir. ARIMA Tekniğine göre, Türkiye'de ölüm sayıları ve iş göremezlik sayılarının 20162020 dönemi için azalacağı tahmin edilmiştir. YSA göre, Türkiye'de ölüm sayıları ve iş göremezlik sayılarının 2016-2020 dönemi için artacağı ön görülmüştür.

Anahtar Kelimeler: İş Kazası, Ölüm, İş göremezlik, ARIMA, Türkiye

\section{ABSTRACT}

As a result death and permanent absence from work are recorded according to years. Data recorded for several years are modeled by time series analysis. In this study, the result of the number of deaths and the number of permanent absence from work in Turkey, using Box-Jenkins (ARIMA) Technique modeled. The same data are also modeled with Artificial Neural Networks. The models obtained as a result of both methods have been compared in terms of estimation. According to estimates for 2016-2020, the model established with Artificial Neural Networks gave more accurate estimates. According to the ARIMA technique, the number of deaths and number of permanent absence from work in Turkey is expected to decrease for the 2016-2020 period. According to ANN, the number of deaths and number of permanent absence from work in Turkey will increase foreseen for the 2016-2020 period.

Keywords: Work Accident, Death, Absence from work, ARIMA, Turkey

Barış ERGÜL - Eskişehir Osmangazi Üniversitesi, Fen-Edebiyat Fakültesi, İstatistik Bölümü, Eskişehir, Türkiye Barış ERGÜL-Eskisehir Osmangazi University, Faculty of Science and Letters, Department of Statistics, Eskisehir, Turkey bergul@ogu.edu.tr 


\section{GİRİŞ}

İş kazaları ve meslek hastalıkları, çalışma hayatının en önemli sorun alanları arasındadır. Küreselleşmenin bir sonucu olarak, sanayileşmenin artması beraberinde ciddi sorunlar meydana getirmektedir. Özellikle üretim ağırlıklı sektörlerin gelişmiş ülkelerden gelişmekte olan ülkelere kayması beraberinde çok fazla sorunu da bu ülkelere kaydırmıştır. Gelişmekte olan ülkelerdeki iş kazası sayısı, buna bağlı olarak ortaya çıkan meslek hastalıkları sayısı ve ölüm oranı hızla artmaktadır. Gelişmekte olan ülkelerde kırsal kesimden kente hızlı göç, eğitim seviyesi düşük işçilerin istihdamı, uygun işlere uygun işçilerin uyarlanamaması, uluslararası firmaların ağ işletmelerinde olumsuz koşullarda çalışma, yetersiz iş denetimi, iş kazaları ve meslek hastalıkları sayının artmasına neden olmaktadır [1]. İş sağlığı, çalışanların beden, ruh ve sosyal iyileştirmelerini sağlamak ve sürdürmek, çalışanların çalışma koşullarından kaynaklanabilecek riskli durumlardan korunmasını ve sağlıklarının bozulmasını önlemek, çalışanların kendilerine uygun işlere yerleştirmesini ve iş ortamına uyumunu sağlamak olarak tanımlanmıştır [2]. İş güvenliği, çalışanları korumak, rahat ve güvenli bir ortamda çalışmalarını sağlamak, işletme güvenliğini sağlayarak tehlikeli durumları ortadan kaldırmak olarak tanımlanabilir [3]. İş Sağlığı ve Güvenliği ise, çalışanların, işyerlerinde işin yürütülmesi nedeniyle oluşacak tehlikelerden korunması, işyeri çevresindeki çalışma koşullarının iyileştirilmesi ve çalışanların huzur içinde çalışmalarını sağlamak amacıyla yapılan sistemli çalışmalardır [4]. İş kazası, belirli bir zarara ya da yaralanmaya neden olan, beklenmeyen bir zamanda meydana gelen ve önceden planlanmamış bir olay olarak tanımlanmıştır [5]. Dünya Sağlık Örgütünün tanımına göre iş kazası, önceden planlanmamış, çoğu kez kişisel yaralanmalara ve üretimin belli bir süre durmasına yol açan bir olaydır [6].
Türkiye’de iş kazası, 6331 sayılı İş Sağlığı ve Güvenliği Kanunu'nun 3. maddesinde tanımlı olduğu gibidir. Bu tanım, işyerinde veya işin yürütümü nedeniyle meydana gelen, ölüme sebebiyet veren veya vücut bütünlüğünü ruhen ya da bedenen engelli hale getiren olay biçiminde tanımlanmıştır [7]. İş kazası kavramının ülkemizdeki hukuki yapısının değerlendirilmesinde 5510 sayılı Sosyal Sigortalar ve Genel Sağlık Sigortası Kanunu esas alınmıştır. Bu yasaya göre iş kazası, sigortalının işyerinde bulunduğu sırada; işveren tarafından yürütülmekte olan iş nedeniyle veya görevi nedeniyle, sigortalı kendi adına ve hesabına bağımsız çalışıyorsa yürütmekte olduğu iş veya çalışma konusu nedeniyle işyeri dışında; bir işverene bağlı olarak çalışan sigortalının, görevli olarak işyeri dışında başka bir yere gönderilmesi nedeniyle asıl işini yapmaksızın geçen zamanlarda; emziren kadın sigortalının, çocuğuna süt vermek için ayrılan zamanlarda; sigortalıların, işverence sağlanan bir taşıtla işin yapıldığı yere gidiş gelişi sırasında meydana gelen ve sigortalıyı hemen veya sonradan bedenen ya da ruhen özre uğratan olay olarak tanımlanmıştır [8].

Dünya genelinde iş kazaları ve meslek hastalıklarının sayısında artış gözlenmektedir. Son yıllarda, ucuz iş gücü nedeniyle gelişmekte olan ülkelere yapılan teknoloji ve sanayi yatırımlarının arttığı görülmektedir. Buna bağlı olarak bu ülkelerdeki çalışma standartlarının kötü olması, meydana gelen iş kazası sayısını da arttırmaktadır. Türkiye'de son yılların istatistiksel verileri incelendiğinde, iş kazası sonucu ölüm, meslek hastalığı ve sakat kalma vakalarında artış olduğu görülmektedir [9]. Türkiye’de 2016 yılında Sosyal Güvenlik Kurumu verilerine göre, 286.068 adet iş kazası meydana gelmiştir. Bir yıl 300 iş günü olarak kabul edildiğinde, Türkiye de her gün yaklaşık 210 iş kazası olmakta, 7 işçi sürekli iş göremez, çalışamaz hale gelmekte ve yine her gün 5 işçi hayatını kaybetmektedir. Bu değerler, Sosyal Güvenlik Kurumu (SGK) istatistiklerinden 
elde edilen resmi sonuçlardır. Yani sadece SGK'ya bildirilen, resmi kayıt alına alınan kazalar için hesaplanan değerlerdir. Meydana gelen her kazanın resmi kayıt altına alınmadığı ve sigortasız olarak çalıştırılan işçilerin ise hiç hesaba katılmadığı düşünüldüğünde olayın boyutları daha da büyüyecektir.

İş kazaları sonucunda iki durum ortaya çıkmaktadır. $\mathrm{Bu}$ durumlar, iş kazası sonucu ölüm ve iş kazası sonucu sürekli iş göremezlik halleridir. İş kazası sonucu ölüm, çalışanın kazayı izleyen günden veya kazadan bir gün sonra başlamak üzere, sonraki bir yıl içinde ölümüyle sonuçlanan iş kazası olarak tanımlanır. Aslında, ölümcül kazaların çoğunluğunda ölüm kazanın meydana geldiği zaman veya kazadan birkaç gün veya birkaç hafta sonra oluştuğu görülmektedir. Sürekli iş göremezlik ise, iş kazası sonucu oluşan hastalık ve özürler nedeniyle kurumca yetkilendirilen sağlık hizmeti sunucularının sağlık kurulları tarafından verilen raporlara istinaden kurum sağlık kurulunca meslekte kazanma gücünün en az \% 10 oranında azalmış olma durumunu ifade etmektedir [10].

İnce v.d. (2000), ülkemizde iş gücü kaybının ele alındığ1 yasaların günün koşullarına uy-gun olarak ve cinsiyet farklılıkları göz önüne alınarak yeniden dü-zenlenmesi gerektiğini ve tüm çalışanlar için standartlaştırılmasının önemini vurgulamışlardır [11]. Yılmaz (2009b), ülkemizde çalışan sayısının artmasıyla iş kazalarının artış gösterdiğini belirtmiştir. Küreselleşmenin olumsuz etkilerini azaltmak için ülkemizde katılımcı bir İSG yönetim modelinin benimsenmesi gerekliliği üzerinde durmuştur [12]. Bıyıkçı (2010), diğer ülke örnekleri ile birlikte iş güvenliği uzmanı kavramının mevzuatımıza girişi, iş sağlığı ve güvenliğinin sağlanmasındaki rolü ve önemini incelemiştir. Ayrıca sağlık ve güvenlik hizmetlerinin yerine getirilmesi sırasında iş güvenliği uzmanının yaşadığı sorunlar için çözüm önerilerinde bulunmuştur [13]. Kılkış ve Demir (2012), İSG faa- liyetleri içinde yer alan işverenin eğitim verme yükümlülügünü çeşitli ülkeler ile Türkiye arasındaki düzenlenme biçimini incelemeye çalışmışlardır [14]. Ceylan (2012), iş kazaların önlenmesinde kritik bir öneme sahip olan, Türkiye'deki İSG eğitimini değerlendirmiştir [15].

İş kazaları adli vakalar olduğundan, iş kazası sonucu oluşan meslek hastalıklarının kayıtlarının ayrıntılı bir şekilde tutulması da oldukça önemlidir. Ilıman (2015), Türkiye'de meslek hastalıklarının tarihi gelişimini, meslek hastalıklarına sebep olan etkenleri ve ilgili mevzuata göre tarafların yükümlülüklerindeki değişimleri ele almışır [16]. Ceylan (2016b), Türkiye'de ve dünya'da meydana gelen çoklu ölümlü iş kazalarını incelemiştir [17]. Tawiah ve Mensah (2016), madencilik sektöründeki yöneticilerin, çalışanların sağlık ve güvenliklerini korumaya yönelik yatırım yapmalar1 gerektiğini belirtmişlerdir [18]. Çetin ve Gögül (2015), rekabete dayalı sürdürülebilir bir büyüme için piyasa ekonomisinin hukuksal zemininin bir an önce yaratılmasının zorunlu olduğunu belirtmişlerdir [19]. Ceylan (2016a), Türkiye'de iş kazalarından kaynaklanan ölüm ve iş göremezlik vakalarını regresyon analizi kullanarak tahmin etmişlerdir [20]. Alper (2017), sosyal güvenlik reformunun kapsamla ilgili hedeflerini değerlendirmiştir [21].

Literatüre bakıldığında son zamanlarda iş kazalarının ve buna bağlı olarak meydana gelen ölüm ve sürekli iş görmezlik sayılarının modellenmesine ilişkin çalışmaların arttığı görülmektedir. Bu değişkenlerin modellenmesi ve tahmini, sadece maddi kayıplar için değil manevi kayıpların önlemesi için alınacak tedbirler içinde gereklidir. Ceylan ve Avan (2013), yapay sinir ağları yardımıyla iş kazası, ölüm ve sürekli iş görmezlik sayılarını 3 farklı senaryo ile öngörmüşlerdir [22]. Erdugan ve Türkan (2017), çalışmalarında 2015 yılında ülkemizde kayıt altına alınmış iş kazalarını log -lineer analiz yöntemini kullanarak istatistiksel olarak anlamlı bir model önermişlerdir [23]. 
Yapılan çalşsmalar incelendiğinde, zamana bağlı olarak kaydedilen iş kazası, ölüm ve işgörmezlik sayılarının, gözlemler arasında bağımsızlık gerektiren yöntemler yardımıyla analiz edildiği görülmektedir. Veriler arasında otokorelasyon bulunması durumunda regresyon analizi etkin sonuçlar vermemektedir. Dolayısıyla buna bağlı olarak yapılacak tahminler gerçeği yansıtmayacaktır. Bir zaman serisi, belirli bir değişkenin zamana göre aldığı değerlerin sıralanması ile oluşur. Zaman serisi analizi ise, geçmiş gözlem değerleri yardımıyla ilgili değişkenin gelecek değerlerinin öngörülmesi ile ilgilidir. Öngörü için çeşitli modeller geliştirilerek, serinin trendi ve özellikleri belirlenmeye çalışılır. Doğrusal zaman serilerinde Box-Jenkins tekniği oldukça başarılı sonuçlar vermektedir. Ayrıca 1980'li yılların sonundan itibaren zaman serilerine ilişkin öngörüler için Yapay Sinir Ağları yöntemi de yaygın olarak kullanılmaktadır [24]. Doğru bir öngörü sonucunda alınacak kararlarda o denli doğru ve başarılı olacaktır. İnsan yaşamını konu alan iş kazalarının sayısının modellenmesi ve öngörülmesinde de doğru yöntemin seçimi, elde edilecek öngörülerin doğruluğunu arttıracaktır.

$\mathrm{Bu}$ çalışmada zaman serisi öngörü tekniklerinden biri olan Box-Jenkins (ARIMA) tekniği ve yapay sinir ağları kullanılarak, Türkiye'deki iş kazaları sonucu ölüm sayıları ve sürekli iş göremezlik süreleri modellenmeye çalışılmıştır.

\section{YÖNTEM}

\section{A. Zaman Serileri Analizi}

Zaman serileri; kesikli, doğrusal ve stokastik süreç içeriyorsa Box-Jenkins modeli olarak adlandırılır. Otoregresif (AR-AutoRegressive) modeller Yule tarafindan düşünülmüştür. $A R(p)$ modeli aşağıdaki gibi ifade edilir:

$y_{t}=\phi_{1} y_{t-1}+\phi_{2} y_{t-2}+\ldots+\phi_{p} y_{t-p}+\epsilon_{t} \quad \epsilon_{t} \sim N\left(0, \sigma^{2}\right)$ $y_{t}$; gelecekteki değerleri öngörülmeye çalışılan bağımlı değişkeni ifade etmektedir. $\phi_{1}, \ldots, \phi_{p}$; denkleminin sağ tarafında bağımlı değişken $y_{t}^{\prime}$ nin p. dereceye kadar olan gecikmeli değerleri için parametre kestirim değerlerini ifade eder. $\epsilon_{t}$; normal dağılıma sahip hata terimini ifade eder.

Diğer bir model, hareketli ortalama (MA-Moving Average) modeli ilk defa Slutsky tarafından ortaya atılmıştır. MA(q) modeli aşağıdaki gibi tanımlanmaktadır:

$y_{t}=\epsilon_{t}+\theta \epsilon_{t-1}+\ldots+\theta \epsilon_{t-q} \quad \epsilon_{i} \sim N\left(0, \sigma^{2}\right)$

$y_{t}$; gelecekteki değerleri öngörülmeye çalışılan bağımlı değişkeni ifade etmektedir. $\theta$; denkleminin sağ tarafında bağımlı değişken $y_{t}^{\prime}$ nin q. dereceye kadar olan gecikmeli değerleri için parametre kestirim değerlerini ifade eder. $\in_{t}$; normal dağılıma sahip hata terimini ifade eder.

AR ve MA modellerinin karışımı olan Otoregresif Hareketli Ortalama (ARMA AutoRegressive Moving Average) modelleri ilk defa Wold tarafından geliştirilmiştir. ARMA $(\mathrm{p}, \mathrm{q})$ modeli ise,

$y_{t}=\alpha+\phi_{1} y_{t-1}+\phi_{2} y_{t-2}+\ldots+\phi_{p} y_{t-p}+\varepsilon_{1}-\theta_{1} \varepsilon_{t-1}-\theta_{2} \varepsilon_{t-2}-\ldots-\theta_{q} \varepsilon_{t-q}$

olarak ifade edilmektedir.

AR, MA, ARMA modelleri en genel doğrusal, durağan Box-Jenkins modelleridir [25].

Gelecekte alacağı değerlerin tahmin edilmeye çalışıldığ seri, durağan değilse seriyi durağan hale getirmek için serinin önce logaritması sonra da uygun dereceden farkı alınır. ARMA (p,q) modelinde kullanılan serinin durağan hale getirilmesi için d kez farkı alınarak model, (p,d,q) dereceden Otoregresif Bütünleşik Hareketli Ortalama (ARIMA) biçiminde ifade edilir. Bu model Box-Jenkins modeli olarak da adlandırılır. Box-Jenkins modellerinde amaç; zaman serisine en iyi uyan, en az parametre içeren doğrusal modeli belirlemektir [26]. ARIMA modelleri için en önemli aşama $p$, $d$ ve $q$ değerlerinin bulunması aşamasıdır. ARIMA mo- 
delinin seçilmesi için bazı stratejiler ortaya konulmuştur ve bu amaçla dört basamaktan oluşan bir deneme - yanılma süreci verilmiştir. İlk aşamada, zaman serisi orjinal gözlemlerinin incelenmesi aşamasıdır. Genel olarak orjinal zaman serisi verileri durağan değildir. İkinci aşamada, farkı alınan serinin $\operatorname{AR}(\mathrm{p}), \operatorname{MA}(\mathrm{q})$ veya $\operatorname{ARMA}(\mathrm{p}, \mathrm{q})$ sürecinden hangisine uyduğunun belirlenmesi için zaman serinin otokorelasyon ve kısmi otokorelasyon fonksiyonundan yararlanilmaktadır. Kısaca, otokorelasyon ve kısmi otokorelasyon grafiklerinin incelenmesi aşaması olarak da bilinmektedir. Sonraki aşamada, BIC (Bayesian Bilgi Kriteri) değerleri belirlenir.

$$
B I C=N \log \hat{\sigma}_{M V}^{2}+k \log N
$$

Burada, $N$; örneklem hacmini, $k$; parametre sayısı ve $\hat{\sigma}_{M V}^{2}$; varyansın en çok olabilirlik kestiricisini göstermektedir.

Denenen geçici modellerde, BIC değerlerinin olabildiğince küçük olması istenir. Geçici model belirlendikten sonra, parametrelerin anlamlılığ 1 ve modelin anlamlılığ 1 test edilir. Modelin genel anlamlılığı, Ljung-Box Q test istatistiği ile sınanır. Son aşmada ise, anlamlı olduğuna karar verilen model yardımıyla ileriye yönelik tahmin yapı$\operatorname{lir}[27,28]$.

\section{B. Yapay Sinir Ağları}

Yapay sinir ağları, bağımlı ve bağımsız değişkenler arasındaki ilişkiyi mevcut duruma uygulayarak genelleme yapmak, bağımsız değişkenlerden yola çıkarak ilgili problemleri çözmeye çalışan bir sistem olarak tanımlanır. Bir sinir ağının davranışı, bağlantıda olduğu hatların ağırlık değerleri ile ölçülmektedir. Bu ağırlıklar sayesinde ağ öğrenmeye başlar ve sonrasında genelleme yapar [29]. Daha ayrıntılı bir ifadeyle, bağımsız değişkenler belli ağırlıklarla çarpılır ve -1 ila +1 arasında değişen eşik değeri ile toplanarak bağımlı değişken oluşturulur. Aktivasyon fonksiyonunda bağımlı değişken üzerinde işlem yapılarak hücre çıktısı istenilen aralıklara getirilmeye çalışılır. Hesap edilen bu bağımlı değişken değeri, gözlenen bağımlı değişken değeri ile karşılaşıııılarak bir hata oranı bulunur. Bu hata oranına göre yapay sinir ağı hücresi, bağımsız değişkenler için yeni ağırlık oranlarını günceller. Böylece daha doğru sonuçlar alabilmemiz için bir döngü sağlanmaktadır. Ağın öğrenme olayı da bu ağırlıkların güncellenmesi ile meydana gelir [22].

Türkiye'de meydana gelen iş kazaları sonucu ölüm sayıları ve iş kazası sonucu iş göremezlik tahmin değerleri için Şekil 1'deki Yapay Sinir Ağları modelleri kullanılarak bulunmuştur. İlk katman girdi değişkenlerinden oluşan giriş veya girdi katmanıdır. Son katman çıktıların yer aldığı çıktı katmanıdır. Arada bulunan gizli katman ise dış ortam ile bağlantısı olmayan nöronlardan oluşur ve bu nöronlar girdi katmanındaki sinyalleri çıktı katmanına gönderirler. Yapay Sinir Ağlarının işleyiş aşamaları daha ayrıntılı biçimde aşă̆ıdaki gibidir: Girdiler, veri üzerinde hiçbir matematiksel işlem yapmadan sadece bir iletim görevi yapmaktadırlar. Girdiler, yapay sinir ağlarının dış dünya ile ilişki halinde olan iki elemanından biridir. Yapay sinir ağına girilen veriler, ağırlıklar aracılığı ile hücrelere girerek bulunduğu girdiyi etkiler. Ağırlıklar bir nevi matematiksel katsayı olarak görev yaparlar. Bir hücreye gelen net girdileri hesaplayan fonksiyon sayesinde net girdiler toplama fonksiyonu aracıllğı ile bulunur. Hücreye gelen net girdiyi işleyerek, ilgili girdiye karşlık üreteceği çıktıyı hesaplama işlemi aktivasyon fonksiyonu sayesinde hesaplanır. Aktivasyon fonksiyonu tarafından çıkı belirlenir. Yapay Sinir Ağlarındaki işlemci elemanların ağırlık değerlerinin belirlenmesi ile ağ eğitilmektedir. Başlangışta bu ağıllık değerleri rassal olarak atanırken, ağa eklenen örnekler ile ağırlık değerleri 
değiştirilir. Ağ doğru değere ulaştığı zaman, genelleme olanağı doğmaktadır [30].

Çalışmada, başlangıç öğrenme oranı 0,4 ; epochsdaki indirgenmiş öğrenme oranı 10 , dengeleme aralığı 0,5 ve iterasyon sayısı 1000 olarak belirlenmiştir.

Şekil 1: Türkiye'de İş Kazası Sonucu Ölüm Sayısı ve İş Göremezlik İçin YSA Modeli

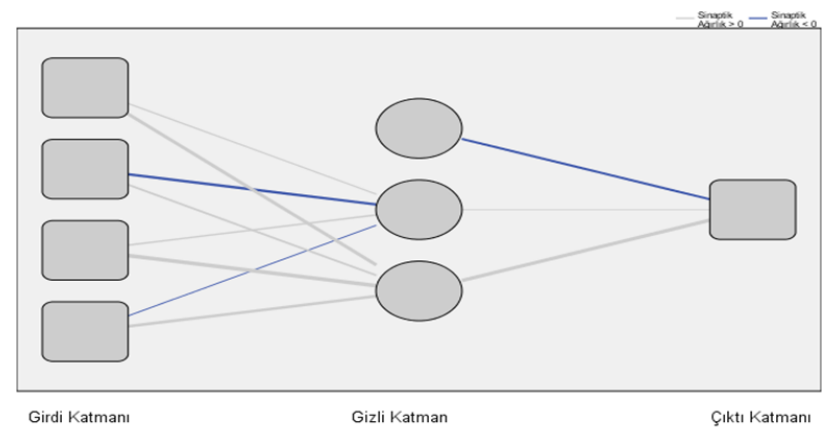

Box-Jenkins ve Yapay Sinir Ağları ile bulunan modellerin karşılaştırılmasında, RMSE (Root Mean Square ErrorOrtalama Hata Kareleri Karekökü) kriteri kullanılmıştır. Literatürde RMSE kriterinden başka, MSE (Mean Sqaure Error-Hata Kareler Ortalaması), MAE (Mean Absolute Error- Ortalama Mutlak Hata) ve SSE (Sum of Squared Error- Hata Kareler Toplamı) gibi bir çok kriter kullanılmıştır. Bu çalışmada, RMSE kriteri kullanılmasının sebebi, literatürde sıklıkla bu kriterin kullanılmış olmasıdır. RMSE aşağıdaki gibi hesaplanır;

$R M S E=\sqrt{\frac{1}{N} \sum_{i=1}^{N} e_{i}^{2}}$

Burada, $N$; örneklem hacmini ve $e_{i}$; hata terimlerini göstermektedir [24].

\section{BULGULAR}

1970-2015 yılları arasında Türkiye'de meydana gelen iş kazaları sonucu ölüm sayıları, TÜİK ve SGK web sayfala- rından alınmıştır. İstatistik Analizler SPSS 18.0 kullanılarak yapılmıştır. Box-Jenkins tekniğinde uygun modelin belirlenmesinde ilk aşama olan geçici modelin saptanması için iş kazası sonucu ölüm sayısı zaman serisinin grafiği ile otokorelasyon fonksiyonu grafiği ve kısmi otokorelasyon fonksiyonu grafikleri Şekil 2-4'te görüldügüü gibidir.

Türkiye’de İş Kazası Sonucu Ölüm Sayıları zaman serinin otokorelasyon ve kısmi otokorelasyon grafikleri incelendiğinde, ilk birkaç otokorelasyon ve kısmi otokorelasyon değerlerinin sınırlar dışında yer aldığı ve diğer gecikme değerlerinin de sınırlar içinde yer aldığı görülmektedir. Serinin durağan olduğuna karar verilmiştir. Şekil 3 ve Şekil 4 incelendiğinde, ilk gecikme değerlerinin anlamsız olduğu görülmüştür.

Şekil 2: Türkiye'de İş Kazası Sonucu Ölüm Sayısı Grafiği

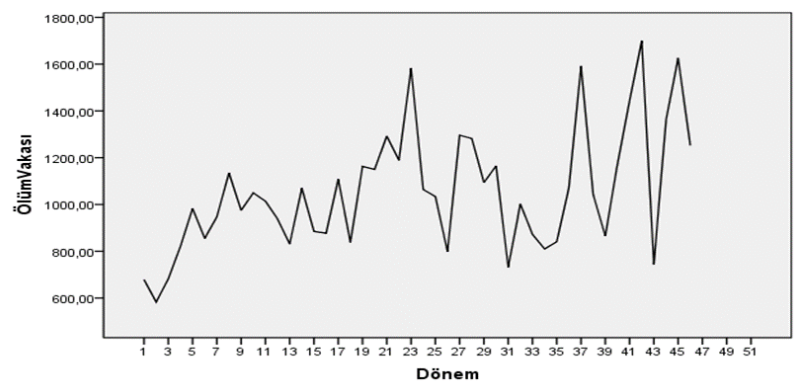

Şekil 3: Türkiye'de İş Kazası Sonucu Ölüm Sayısı ACF Grafiği

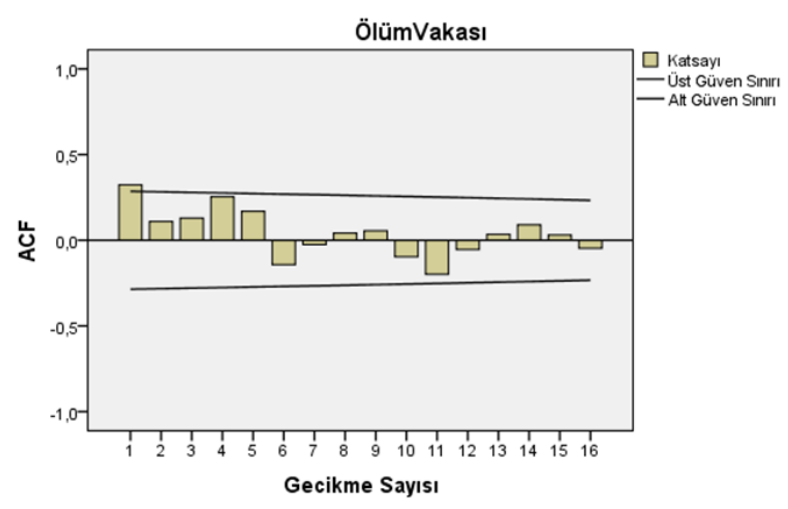


Şekil 4: Türkiye'de İş Kazası Sonucu Ölüm Sayısı PACF Grafiği

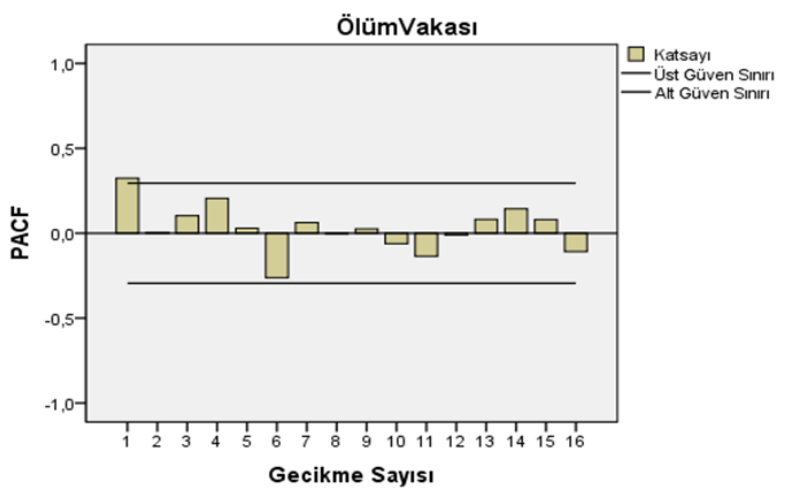

Daha sonraki aşamada ise ilgili zaman serisi için çeşitli ARIMA modelleri denenmiştir. Sonuçlar Tablo 1' de verildiği gibidir. Tablo 1 ve Tablo 2 incelendiğinde ARIMA $(1,0,0)$ modelinin BIC kriterine göre en düşük değeri alan model olduğu görülmektedir. Ayrıca modelin parametre tahminlerinin anlamlılığını test etmek için hesaplanan olasllık değeri ( $\mathrm{p}), \alpha=0,05$ anlamlılık düzeyinden küçük oldugundan parametre tahminleri de anlamlidır. Bu nedenle ARIMA $(1,0,0)$ modelinin geçici uygun model olduğu düşünülerek işlemlere devam edilmiştir.

Tablo 1: Türkiye'de İş Kazası Sonucu Ölüm Sayıları İçin Farklı ARIMA Modelleri ve BIC değerleri

\begin{tabular}{cc}
\hline ARIMA Modelleri & BIC Değerleri \\
\hline $\operatorname{ARIMA}(1,0,0)$ & 11.208 \\
$\operatorname{ARIMA}(1,0,1)$ & 11.296 \\
$\operatorname{ARIMA}(1,1,1)$ & 11.213 \\
$\operatorname{ARIMA}(0,0,1)$ & 11.220 \\
$\operatorname{ARIMA}(1,1,0)$ & 11.431 \\
$\operatorname{ARIMA}(0,1,1)$ & 11.129 \\
\hline
\end{tabular}

ARIMA $(1,0,0)$ modeli için hata terimleri otokorelasyon ve kısmi otokorelasyon fonksiyonu grafikleri Şekil $5^{`} \mathrm{de}$ çizilmiştir. Grafikler incelendiğinde, hata terimlerinin s1nırlar içinde kaldığı görülmektedir.
Tablo 2: Türkiye'de İş Kazası Sonucu Ölüm Sayıları İçin ARIMA $(1,0,0)$ Parametre Kestirim Değerleri

\begin{tabular}{ccccc}
\hline Parametre & Kestirim & SE & $\mathbf{t}$ & $\mathbf{p}$ \\
\hline Sabit & 1052.590 & 54.776 & 19.216 & 0.000 \\
AR & 0.336 & 0.143 & 2.358 & 0.023 \\
\hline
\end{tabular}

Şekil 5: Türkiye'de İş Kazası Sonucu Ölüm Sayıları İçin ARIMA $(1,0,0)$ Hata Terimleri ACF ve PACF

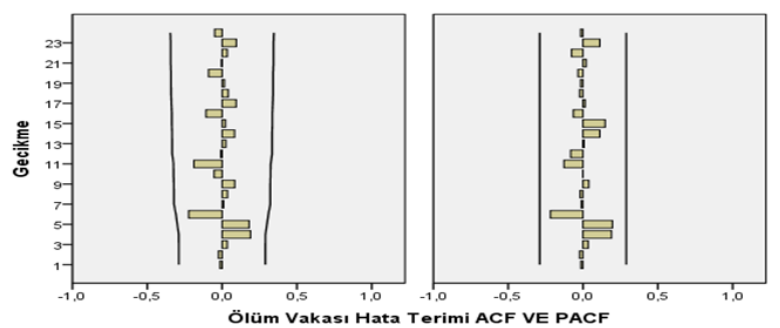

Geçici modelin uygunluğu, Ljung-Box testi ile test edilir. Ljung-Box testi sonucu Tablo 3’te gösterilmiştir.

Tablo 3: Türkiye'de İş Kazaları Sonucu Ölüm Sayıları İçin ARIMA $(1,0,0)$ LJUNG-BOX İstatistikleri

\begin{tabular}{ccc}
\hline istatistik & df & p \\
\hline 11.646 & 17 & 0.821 \\
\hline
\end{tabular}

Geçici modelin uygun model olduğuna Ljung-Box istatistiği ile karar verilir $(\mathrm{p}>0.05)$.

ARIMA $(1,0,0)$ modeli kullanılarak, yıllar itibariyle Türkiye'deki iş kazası sonucu ölüm sayıları zaman serisinin değerlerine ilişkin 2016-2020 dönemi için öngörüler yapılmıştır. İleriye yönelik tahmin değerleri Tablo 4'de verilmiştir. Bu dönem için öngörü yapılmasının nedeni ARIMA modellerinin kısa dönem öngörüsünde başarılı sonuçlar vermesidir.

1970-2015 yılları arasında Türkiye'de meydana gelen iş kazaları sonucu sürekli iş göremezlik sayıları modellenmiştir. Box-Jenkins tekniğinde uygun modelin belirlenmesin- 
Tablo 4: Türkiye’de İş Kazaları Sonucu Ölüm Sayıları ARIMA ile İleriye Yönelik Tahmin Değerleri

\begin{tabular}{cccc}
\hline Dönem & $\begin{array}{c}\text { Ölüm Sayısı } \\
\text { Tahmin Değeri }\end{array}$ & $\begin{array}{c}\text { Ölüm Sayısı Üst } \\
\text { Limit }\end{array}$ & $\begin{array}{c}\text { Ölüm Sayısı Alt } \\
\text { Limit }\end{array}$ \\
\hline 2016 & 1120 & 1622 & 618 \\
2017 & 1075 & 1605 & 545 \\
2018 & 1060 & 1593 & 527 \\
2019 & 1055 & 1588 & 521 \\
2020 & 1053 & 1585 & 519 \\
\hline
\end{tabular}

de ilk aşama olan geçici modelin saptanması için iş kazası sonucu sürekli iş göremezlik zaman serisinin grafiği ile otokorelasyon fonksiyonu grafiği ve kısmi otokorelasyon fonksiyonu grafikleri Şekil 6-8'de görüldüğü gibidir. Türkiye'de İş Kazası Sonucu İş Göremezlik sayıları zaman serinin otokorelasyon ve kısmi otokorelasyon grafikleri incelendiğinde, ilk birkaç otokorelasyon ve kısmi otokorelasyon değerlerinin sınırlar dışında yer aldığı görülmüştür. Serinin durağan olmadığına karar verilmiştir. Şekil 7 ve Şekil 8 incelendiğinde, ilk 6 gecikme değerine ait otokorelasyon değerlerinin anlamsız olduğu ancak bu değerlerin azalması nedeni ile mevsimsellik olmadığına karar verilmiştir. Ek olarak ilk gecikme için kısmi otokorelasyon değerinin anlamsız olması da mevsimsellik olmadığını desteklemektedir. Daha sonraki aşamada ise ilgili zaman serisi için çeşitli ARIMA modelleri denenmiştir. Sonuçlar Tablo 5' de verildiği gibidir.

Şekil 6: Türkiye'de İş Kazası Sonucu Sürekli İş Göremezlik Sayıları Grafiği

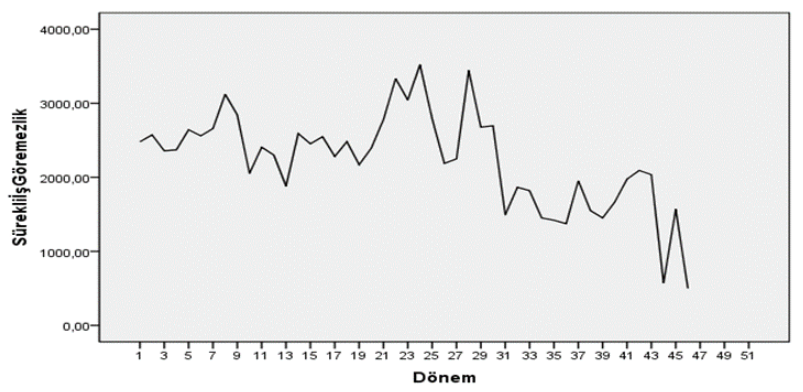

Şekil 7: Türkiye'de İş Kazası Sonucu Sürekli İş Göremezlik Sayıları ACF Grafiği

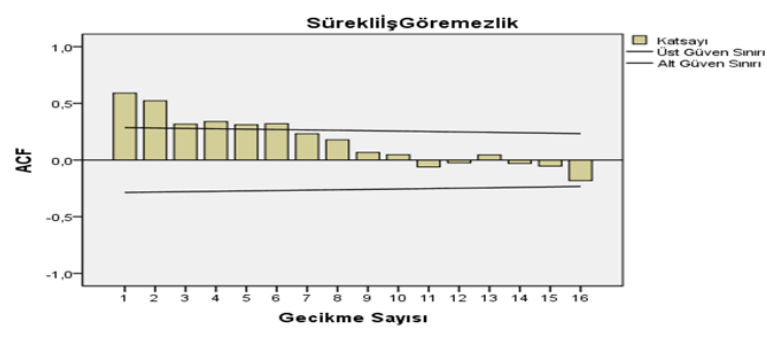

Şekil 8: Türkiye'de İş Kazası Sonucu Sürekli İş Göremezlik Sayıları PACF Grafiği

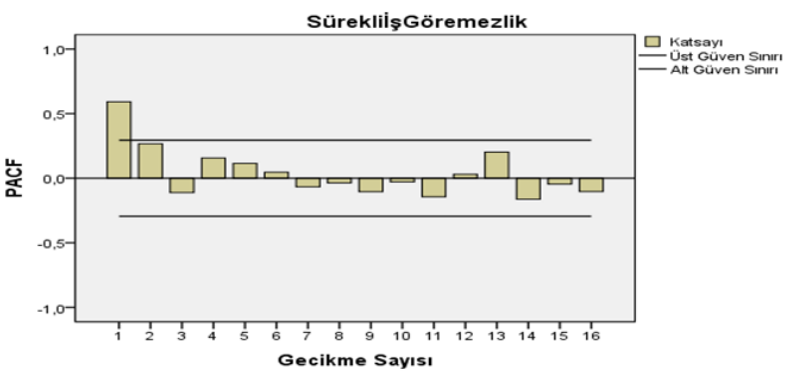

Tablo 5 ve Tablo 6 incelendiğinde ARIMA $(1,1,0)$ modelinin BIC kriterine göre en düşük değeri alan model olduğu görülmektedir. Ayrıca modelin parametre tahminlerinin anlamlılığını test etmek için hesaplanan olasılık değeri (p), $\alpha=0,05$ anlamlılık düzeyinden küçük olduğundan parametre tahminleri de anlamlıdır. Bu nedenle ARIMA $(1,1,0)$ modelinin geçici uygun model olduğu düşünü-

Tablo 5: Türkiye'de İș Kazası Sonucu İş Göremezlik Sayısı İçin Farklı ARIMA Modelleri ve BIC değerleri

\begin{tabular}{cc}
\hline ARIMA Modelleri & BIC Değerleri \\
\hline $\operatorname{ARIMA}(1,0,0)$ & 12.611 \\
$\operatorname{ARIMA}(1,0,1)$ & 12.640 \\
$\operatorname{ARIMA}(1,1,1)$ & 12.636 \\
$\operatorname{ARIMA}(0,0,1)$ & 12.877 \\
$\operatorname{ARIMA}(1,1,0)$ & $\mathbf{1 2 . 5 7 5}$ \\
$\operatorname{ARIMA}(0,1,1)$ & 12.540 \\
$\operatorname{ARIMA}(0,1,2)$ & 12.643 \\
$\operatorname{ARIMA}(1,1,2)$ & 12.743 \\
\hline
\end{tabular}


Tablo 6: Türkiye'de İş Kazası Sonucu İş Göremezlik İçin ARIMA $(1,1,0)$ Parametre Kestirim Değerleri

\begin{tabular}{ccccc}
\hline Parametre & Kestirim & SE & $\mathbf{t}$ & $\mathbf{p}$ \\
\hline Sabit & -38.240 & 22.721 & -1.683 & 0.049 \\
AR & -0.405 & 0.146 & -2.764 & 0.008 \\
Fark & 1 & & & \\
\hline
\end{tabular}

lerek işlemlere devam edilmiştir. ARIMA $(1,1,0)$ modeli için hata terimleri otokorelasyon ve kısmi otokorelasyon fonksiyonu grafikleri Şekil 9`da çizilmiştir. Grafikler incelendiğinde, hata terimlerinin sınırlar içinde kaldığı görülmektedir.

Şekil 9: Türkiye'de İş Kazası Sonucu İş Göremezlik Süre İçin ARIMA $(1,1,0)$ Hata Terimleri ACF ve PACF

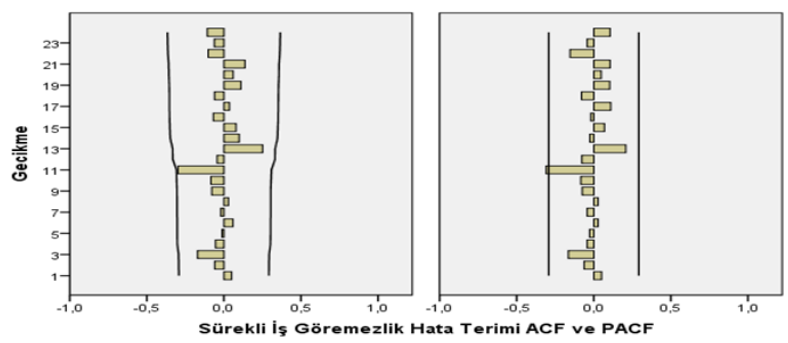

Geçici modelin uygunluğu, Ljung-Box testi ile test edilir. Test sonucu Tablo 7'de verilmiştir. Geçici modelin uygun model olduğuna Ljung-Box istatistiği ile karar veri$\operatorname{lir}(\mathrm{p}>0.05)$.

Tablo 7: Türkiye’de İş Kazaları

Sonucu İş Göremezlik Sayı İçin $\operatorname{ARIMA}(1,1,0)$ LJUNG-BOX İstatistikleri

\begin{tabular}{ccc}
\hline İstatistik & df & p \\
\hline 16.245 & 17 & 0.507 \\
\hline
\end{tabular}

ARIMA $(1,1,0)$ modeli kullanılarak, yıllar itibariyle Türkiye'deki iş kazası sonucu iş göremezlik sayıları zaman serisinin değerlerine ilişkin 2016-2020 dönemi için öngörüler yapılmıştır. Tahmin değerleri Tablo 8 'de görüldüğü gibidir. Bu dönem için öngörü yapılmasının nedeni ARI-
MA modellerinin kısa dönem öngörüsünde başarılı sonuçlar vermesidir.

Tablo 8: Türkiye'de İş Kazaları Sonucu İş Göremezlik Sayı İçin ARIMA ile İleriye Yönelik Tahmin Değerleri

\begin{tabular}{cccc}
\hline Dönem & $\begin{array}{c}\text { iş̧ Göremezlik } \\
\text { Tahmin Değeri }\end{array}$ & $\begin{array}{c}\text { iş Göremezlik } \\
\text { Üst Limit }\end{array}$ & $\begin{array}{c}\text { iş Göremezlik } \\
\text { Alt Limit }\end{array}$ \\
\hline 2016 & 880 & 1876 & 117 \\
2017 & 672 & 1831 & 487 \\
2018 & 702 & 2087 & 582 \\
2019 & 636 & 2184 & 595 \\
2020 & 609 & 2315 & 576 \\
\hline
\end{tabular}

Benzer şekilde, 1970-2015 yılları arasında Türkiye'deki çalışan sayıları, iş yeri sayıları ve iş kazaları sayıları BoxJenkins ARIMA modelleri ile modellenmiş ve 2016-2020 dönemi için öngörüler yapılmıştır. Çalışan Sayısı için ARIMA $(1,1,1)$, İş Yeri Sayısı için ARIMA $(1,1,0)$ ve İş Kazası Sayısı için ARIMA $(0,2,1)$ modelleri ile bulunan tahmin değerleri Tablo 9'da gösterilmiştir. Analiz sonucunda belirlenen ARIMA modelleri doğrultusunda 2016-2020 yılları için ileriye yönelik tahmin yapılmıştır. İki zaman serisi için tahmin değerleri Tablo 9'da gösterilmiştir.

Tablo 9: Türkiye'de İş Kazaları Sonucu Ölüm Sayıları ve İş Göremezlik İleriye Yönelik ARIMA Tahmin Değerleri

\begin{tabular}{ccc}
\hline Dönem & $\begin{array}{c}\text { Ölüm Sayısı Tahmin } \\
\text { Değeri }\end{array}$ & $\begin{array}{c}\text { İ̧̧ Göremezlik Tahmin } \\
\text { Değeri }\end{array}$ \\
\hline 2016 & 1120 & 880 \\
2017 & 1075 & 672 \\
2018 & 1060 & 702 \\
2019 & 1055 & 636 \\
2020 & 1053 & 609 \\
\hline
\end{tabular}

2016 dönemi için Türkiye’de iş kazaları sonucu ölüm sayısı 1120 olarak tahmin edilmiştir. Yine aynı dönem için iş göremezlik sayısı tahmin değeri 880 olarak bulunmuştur. Analiz sonuçlarına göre, Türkiye’de ölüm sayıları ve iş göremezlik sayılarının 2016-2020 dönemi için azalacağı ön 
görülmüştür.

Tablo 10: Türkiye'deki Çalışan Sayıları, İş Yeri Sayıları ve İş Kazası İçin İleriye Yönelik Tahmin Değerleri

\begin{tabular}{cccc}
\hline Dönem & $\begin{array}{c}\text { Çalışan Sayısı } \\
\text { Sayısı Tahmin } \\
\text { Değeri }\end{array}$ & $\begin{array}{c}\text { İş Yeri Sayısı } \\
\text { Sayısı Tahmin } \\
\text { Değeri }\end{array}$ & $\begin{array}{c}\text { İş Kazası Sayısı } \\
\text { Sayısı Tahmin } \\
\text { Değeri }\end{array}$ \\
\hline 2016 & 14675571 & 1801984 & 278868 \\
2017 & 15322804 & 1865404 & 319959 \\
2018 & 15943942 & 1930322 & 365056 \\
2019 & 16541102 & 1996611 & 414396 \\
2020 & 17116231 & 2064174 & 468223 \\
\hline
\end{tabular}

Sonraki aşamada aynı veriler kullanılarak YSA yapılmıştır. Bu aşamada, Tablo 10 'da bulunan ilgili zaman serileri değerleri bağımsız değişken olarak kullanılıp YSA ile iş kazaları sonucu ölüm sayıları ve iş göremezlik sayıları tahmin edilmiştir. İlgili tahmin değerleri Tablo 11'da verilmiştir.

Tablo 11: Türkiye'de İş Kazaları Sonucu Ölüm Sayıları ve İş Göremezlik İleriye Yönelik YSA Tahmin Değerleri

\begin{tabular}{ccc}
\hline Dönem & $\begin{array}{c}\text { Ölüm Sayısı Tahmin } \\
\text { Değeri }\end{array}$ & $\begin{array}{c}\text { iş̧ Göremezlik Tahmin } \\
\text { Değeri }\end{array}$ \\
\hline 2016 & 1360 & 1704 \\
2017 & 1373 & 2051 \\
2018 & 1384 & 2082 \\
2019 & 1393 & 2015 \\
2020 & 1399 & 1944 \\
\hline
\end{tabular}

\section{SONUÇ VE ÖNERIILER}

Bu çalışmada, 1970-2015 dönemi arasında Türkiye’de meydana gelen iş kazaları sonucu ölüm ve iş göremezlik için zaman serisi verileri ARIMA tekniği ile analiz edilmiştir. Analiz sonucunda belirlenen ARIMA modelleri doğrultusunda 2016-2020 yılları için ileriye yönelik tahmin yapılmıştır.

2016 dönemi için Türkiye'de iş kazaları sonucu ölüm sayısı 1120 olarak tahmin edilmiştir. Yine aynı dönem için iş göremezlik sayısı tahmin değeri 880 olarak bulunmuştur. Analiz sonuçlarına göre, Türkiye’de ölüm sayıları ve iş göremezlik sayılarının 2016-2020 dönemi için azalacağı ön görülmüş̧ür.

1970-2015 dönemi arasında Türkiye'de meydana gelen iş kazaları sonucu ölüm ve iş göremezlik için zaman serisi verileri, YSA kullanılarak analiz edilmiştir. Analiz sonucunda belirlenen YSA doğrultusunda 2016-2020 yılları için ileriye yönelik tahmin yapılmıştır. 2016 dönemi için Türkiye’de iş kazaları sonucu ölüm sayısı YSA modeli ile 1360 olarak tahmin edilmiştir. Yine aynı dönem için iş göremezlik sayısı tahmin değeri 1704 olarak bulunmuştur. Analiz sonuçlarına göre, Türkiye’de ölüm sayıları ve iş göremezlik sayılarının 2016-2020 dönemi için artacağı ön görülmüştür.

Türkiye’de İş Kazaları sonucu ölüm sayıları ve iş göremezlik sayıları için RMSE değerleri Tablo 12'de gösterilmiştir. Ölüm sayısı için hesaplanan RMSE değerleri karşılaştırıldığında, YSA modeli için RMSE değeri en küçük bulunmuştur. Benzer şekilde, iş göremezlik RMSE değerleri karşılaştırıldığında en uygun modelin YSA modeli olacağı söylenir. Burada dikkat çeken bir diğer husus da, ARIMA modelleri için bulunan RMSE değerleri, Yapar Sinir Ağları ile oluşturulan modellerden daha büyük bulunmuştur. ARIMA modelleri yerine Yapay Sinir Ağları ile tahmin yapmak daha doğru sonuçlar verecektir.

Tablo 12: Türkiye'de İş Kazaları Sonucu Ölüm Sayıları ve İş Göremezlik İleriye Yönelik ARIMA ve YSA Tahmin Değerleri için RMSE

\begin{tabular}{ccc}
\hline RMSE & ARIMA & YSA \\
\hline Ölüm Sayısı & 249.883 & $\mathbf{2 0 7 . 4 2 8}$ \\
İş Göremezlik & 480.659 & $\mathbf{3 9 2 . 7 9 4}$ \\
\hline
\end{tabular}




\section{KAYNAKLAR}

[1] Karadeniz, O. (2012). Dünya'da ve Türkiye’de İș Kazaları ve Meslek Hastalıkları ve Sosyal Koruma Yetersizliği. Çalı) ma ve Toplum, Cilt:3.

[2] Yilmaz, F. (2009). Avrupa Birli, $i$ ve Türkiye'de $\dot{I}_{s}$

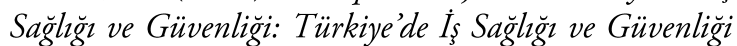
Kurullarmın Etkinlik Düzeyinin Ölçülmesi. şstanbul Üniversitesi SBE, Basılmamış Doktora Tezi, İstanbul.

[3] Ünsar, S. (2003). Türkiye'de İş̧i Sağlı̆̆ ve İş Güvenligi Uygulamalarmon Mevcut Durumu ve Konuyla İlgili Yapılan Bir Araştırma. ş.Ü. Sosyal Bilimler Enstitüsü, Basılmamış Doktora Tezi, İstanbul.

[4] Topak, O. (2004). İşçiden İş Kavramına Geçiş ve Değişikliğin Gizli İdeolojisi. Mesleki Sa) lık ve Güvenlik Dergisi, Türk Tabipler Birliýi Yayını.

[5] Jorgensen, K. (1998), Accidents and Safety Management Chapter 56: Accident Prevention, Concepts of Accident Analysis. Encyclopaedia of Occupational Health and Safety, 4th Ed., Geneva, ILO Publication, Vol: 2, Part VIII.

[6] World Health Organization, (2007). Declaration on Occupational Health for All.

[7] Erginel, N. \& Toptancı, Ş. (2017). İş Kazası Verilerinin Olasılık Dağılımı İle Modellenmesi. Journal of Engineering Sciences and Design.

[8] Karaman, E.A., Çivici, T. \& Kale, S. (2011). $\left.{ }_{4}\right)_{c ̧} i$ Sağlı̆̆ı ve İs Güvenliğinin İnşaat Sektöründeki Yeri ve Önemi. 3. şçi Saýlıýi ve ş Güvenliýi Sempozyumu, Çanakkale.

[9] Çavuş, A. \& Taçgın, E. (2015). Türkiye'de İnşaat Sektöründeki İş Kazalarının Sınıflandırılarak Nedenlerinin İncelenmesi. APJES, Vol:4, Issue:2.

[10] Sosyal Güvenlik Kurumu, (2016). 4) Kazası ve Meslek Hastalıkları İstatistikleri.

[11] İnce, H., İnce, N. \& Tüzün, B. (2000). İş Kazaları ve Çalışma Gücü Kayıplarının Türkiye'deki Yasal Düzenlemeleri. Adli Tip Bülteni, Cilt: 5, Sayı:1.

[12] Yılmaz, F. (2009). Küreselleşme sürecinde gelişmekte olan ülkelerde ve Türkiye'de iş sağlığı ve güvenliği. Uluslararası Bilim Dergisi, Cilt:6, Sayı:1.

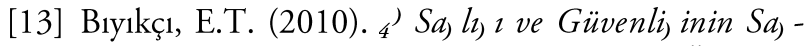
lanmasında Isş Güvenliğgi Uzmanlığı. UludaÝ Üniversitesi SBE, Yüksek Lisans Tezi.

[14] Kılkış, İ. \& Demir, S. (2012). İşverenin İş Sağlığı ve Güvenliği Eğitimi Verme Yükümlülügü Üzerine Bir İnceleme. Çalı) ma 4 li)kileri Dergisi, Cilt:3, Sayı:1.
[15] Ceylan, H. (2012). Türkiye’deki İş Sağlığı ve Güvenliği Eğitimi Sorunlar ve Çözüm Önerileri. Electronic Journal of Vocational Colleges.

[16] Ilıman, E.Z. (2015). Türkiye'de Meslek Hastalıkları. Uluslararası Să̆lık Yönetimi ve Stratejileri Araştırma Dergisi, Cilt:1, Sayı:1.

[17] Ceylan, H. (2016). 2014 Yılında Türkiye'de Meydana Gelen Ölümlü İş Kazalarının Analizi. Uluslararası Mühendislik Araştırma ve Geliştirme Dergisi, Cilt:8, Sayı:1.

[18] Tawiah, K. \& Mensah, J. (2016). Occupational Health and Safety and Organizational Commitment: Evidence from the Ghanaian Mining Industry. Safety and Health At Work, Vol: 7.

[19] Çetin, M. \& Gögül, P. (2015). Türkiye'deki Iss Kazaları ve Isşi Ölümlerinin Ekonomik Boyutu ve Politika Önerisi. Sosyoloji Konferansları.

[20] Ceylan, H. (2016). Türkiye'de İş Kazalarından Kaynaklanan Ölüm ve Sürekli İş Göremezlik Vakalarının Regresyonla Tahmini. Uluslararası Mühendislik Ara)tırma ve Geliştirme Dergisi, Cilt:8, Sayı:2.

[21] Alper, Y. (2017). Sosyal Güvenlik Reformu (20082016): Kapsamla İlgili Gelişmeler. Sosyal Siyaset Konferansları, Sayı: 68.

[22] Ceylan, H. \& Avan, M. (2013). Türkiyede’ki İş Kazalarının Yapay Sinir Ağları ile 2025 Yılına Kadar Tahmini. International Journal of Engineering Research and Development, Vol.4, No.1.

[23] Erdugan, F. \& Türkan, A.H. (2017). Üç Yönlü Kontenjans Tablolarında Log-Lineer Model ile İş Kazası Verilerinin İncelenmesi. Karaelmas Fen ve Müh. Derg., 7(2), 462-468.

[24] Ataseven, B. (2013). Yapay Sinir Ağları ile Öngörü Modellemesi. Öneri Dergisi, Cilt: 10, Sayı: 39, 101115.

[25] Priestley, M.B. (1991). Non-Linear and NonStationary Time series Analysis. Academic Press, London.

[26] Hamzaçebi, C. \& Kutay, F. (2004). Yapay sinir ağları ile Türkiye elektrik enerjisi tüketiminin 2010 yılına kadar tahmini. Gazi Üniversitesi Mühendislik Mimarlık Fakültesi Dergisi, Cilt:19, No.3.

[27] Akgül, İ. (2003). Zaman Serilerinin Analizi ve ARIMA Modelleri. Der Yayınları, şstanbul.

[28] Kadılar, C. (2005). SPSS Uygulamalı Zaman Serileri Analizine Giriş. Bizim Büro Basımevi, Ankara.

[29] Karaatlı, M., Güngör, İ. \& Demir, Y. (2005). Hisse Senedi Fiyat Hareketlerinin Yapay Sinir Ağları Yönte- 
mi ile Tahmin Edilmesi. Yönetim ve Ekonomi Ara'tırmaları Dergisi, Cilt:2, Sayı:3.

[30] Karahan, M. (2011). ${ }_{4}$ statistiksel Tahmin Yöntemleri: Yapay Sinir Ağlar ile Ürün Talep Tahmini Uygulaması. Selçuk Üniversitesi SBE, Basılmamı Doktora Tezi, Konya. 